\title{
Archives of Ecotoxicology
}

\author{
Journal homepage: https://office.scicell.org/index.php/AE
}

\section{Harnessing Acremonium zonatum (Sawada) Gams oil formulations as water hyacinth control mycoherbicides}

\author{
Chrispo Mutebia*, George Opandeb \\ ${ }^{a}$ Kenya Agricultural and Livestock Research Organization, P.O Box 1490 - 40100, Kisumu, Kenya \\ ${ }^{b}$ Department of Biological \& Agricultural Sciences, School of Science, Kaimosi Friends University College. P.O BOX 385 - 50309 , Kaimosi, Kenya
}

\begin{tabular}{|c|c|}
\hline Article info & Abstract \\
\hline $\begin{array}{l}\text { Recelved } 8 \text { April } 2021 \\
\text { Revised } 5 \text { September } 2021\end{array}$ & The effect of formulating Acremonium zonatum (Saw.) Gams in corn oil, mineral oil and glycerol was \\
\hline Accepted 6 September 2021 & determined in a glasshouse at Maseno University Botanic Garden and laboratory. The study was situated at \\
\hline Published online 30 September 2021 & $\begin{array}{l}\text { latitude }-1^{\circ} 0^{\prime} 00^{\prime \prime} \mathrm{S} \text { and longitude } 34^{\circ} 36^{\prime} 00^{\prime \prime} \text { E. A. zonatum was aseptically isolated from symptomatic plants } \\
\text { and inoculated upon healthy water hyacinth plants in a CRD experiment. Data was analyzed using SPSS }\end{array}$ \\
\hline Regular article & $\begin{array}{l}\text { version } 20 \text { computer software. Oil and spore density effects were statistically significant at } p<0.05 \text {. The } \\
\text { main effect of oil yielded an effect size of } 0.281 \text { indicating that } 28.1 \% \text { of the variance in disease severity }\end{array}$ \\
\hline Keywords: & was explained by the oil formulation $(F(2,28)=5.459, p=0.01)$. Spore density yielded an effect size of \\
\hline Disease severity; & 0.326 indicating that $32.6 \%$ of the variance in the study was explained by spore density $(F(3,28)=4.515$, \\
\hline Eichhornia crasipess; & $p=0.011)$. The interaction effect was not significant $(F(6,28)=0.199, p=0.974)$ indicating that there was \\
\hline Fresh water lakes; & no combined effect for the kind of oil used in the formulation of the $A$. zonatum and the spore density. The \\
\hline Fungal agent; & results suggested that $A$. zonatum pathogenicity varies with different spore concentrations, $1 \mathrm{x} 10^{8}$ \\
\hline $\begin{array}{l}\text { High growth rate; } \\
\text { Invasive species }\end{array}$ & $\begin{array}{l}\text { spores } / \mathrm{ml} \text { being the most potent. } A \text {. zonatum has favorable characteristics for consideration as a } \\
\text { mycoherbicide. Corn oil as formulation material was concluded to be the best formulation material for } A \text {. } \\
\text { zonatum. }\end{array}$ \\
\hline
\end{tabular}

\section{Introduction}

Water hyacinth (Eicchornia crassipes (Mart. [Sol.] Laubach) has been reported as the worst water weed in the world (Mengist and Moges, 2019). The weed has accelerated growth and biomass accumulation that impede navigation, water harvesting and it fouls fishing nets and traps (Su et al., 2018). A native of the Amazon Basin in South America it is invasive in fresh water bodies with negative impact (Dersseh and Dessalegn, 2019). It is adapted to wide variety of water bodies that include; running stream water, drainage ditches, stagnant water ponds and irrigation canal (Fawad and Jamal, 2019). Fresh water lakes in the tropics have continued to experience the water hyacinth menace due to eutrophication, one of the major ecological concerns over the world in recent times (Biswajit and Kamal, 2019).

The principal drawback with biological control has been the period required to achieve control (Yigermal et al., 2020) and this can be tied to the low pathogenicity of the pathogens that have been deployed and the media through which they have been deployed. Water hyacinth is reported to have a high proliferation rate (Obianuju et al., 2020). The high growth rate of water hyacinth and the high cost involved in its eradication make the existing control techniques insufficient to contain its antagonistic propagation therefore driving empirical investigations for alternative mitigation (Obianuju et al., 2020).

In using vegetable oils for formulating fungi refined oils are preferred over unrefined because often times unrefined oils are usually contaminated by heavy metals that may affect the fungi in question (Flora et al., 2018). Among the oils investigated, sunflower and mustard oils were more stable than rapeseed, peanut and olive oils (Konuskan et al., 2019).

Oil formulations are reported to improve efficacy of biopathogens (Karim et al., 2011; Berestetskiy and Sokornova, 2018). Forms of water hyacinth control with the use of bioherbicides should be encouraged so as to preserve environmental quality and human health (Bordin et al., 2020). Obianuju et al. (2020) have observed that the fundamental relationship between viability and implementation of any mitigation strategy is on the hypothesis that stakeholders will be keen to adopt a technique if it offers higher profits or efficacy than the current mitigation measures.

\section{Material and methods}

The study was conducted in the glasshouse at Maseno University Botanic Garden and laboratory. The geographical co-ordinates in degrees minutes seconds are latitude $-1^{\circ} 0^{\prime} 00^{\prime \prime} \mathrm{S}$ and longitude $34^{\circ} 36^{\prime} 00^{\prime \prime} \mathrm{E}$. The climate is tropical with an average 
temperature of $26.6^{\circ} \mathrm{C}$. The temperatures in February average $21.4^{0} \mathrm{C}$ while July has the lowest average of $19.6^{\circ} \mathrm{C}$.

Water hyacinth plants showing zonate leaf spot (A. zonatum) symptoms were collected from Lake Victoria fronts and taken to the laboratory. Five plants were collected from each of the locations and put in a polythene bag containing water. Even dried leaves with symptoms were also collected. They were ferried to the laboratory and kept at room temperature pending isolation of the pathogen.

The diseased plants were washed in running tap water and rinsed in sterile water. Excess water was shaken off. Using the standard laboratory isolation procedures of Dhingra and Sinclair (1995), the leaves with lesions were cut from the plants and placed on a sterile blotting paper. $1 \mathrm{~mm}^{2}$ pieces were cut from the margins of the necrotic lesions on the leaves, surface disinfected in $0.5 \%$ sodium hypochlorite for 1 minute and in $70 \%$ ethanol for 30 seconds. The sterilized leaves were transferred to Potato Dextrose Agar (PDA) medium on plastic plates under aseptic conditions following the procedure by Martinez and Charudattan (1998). The plates were sealed with parafilm membrane and incubated at room temperature on the laboratory benches. After the formation of milky white fluffy material on the media indicating mycelia growth, sub culturing was done to obtain pure culture, by transferring mycelia to fresh PDA using a fine sterile needle.

Using a sterile wire loop, material was scraped from the surface of the sporulating culture and microscopically examined at low power (x10) in a drop of water. The fungus were identified using the descriptions of Olga (1986).

Koch's postulation was also followed to confirm the identity of the pathogen by cutting $5 \mathrm{~mm}$ diameter agar blocks of the pure culture from the isolation, placing on the leaves of young healthy water hyacinth plants that had been injured by rubbing with quartz. The infected leaves were kept covered with a polythene bag for 48 hours. The plants were observed for 10 days for disease symptoms.

The sub cultures grown on PDA plates were multiplied by picking mycelia with a sterile needle and transferring the same to other plates and incubating at room temperature.

Agar plates with $A$. zonatum colony growth were flooded with $2 \mathrm{ml}$ of the respective oil emulsions and spores removed from the agar surface using a flame sterilized glass rod and shaking slightly. The suspension was filtered through a nylon mesh sieve to remove large mycelia particles. The harvested spores were kept in sterilized $10 \mathrm{ml}$ beakers.

A haemocytometer was used to determine the concentration of the spores in the suspension employing the method created by Caprette (2000). The concentration was adjusted, by serial dilution, to $10^{8}, 10^{7}, 10^{6}$ and $10^{5}$ spores/ml. These concentrations were chosen for use in the study in conformity with El-Morsy (2004) who established that $10^{6}$ fungal spores/ml is the threshold inoculum concentration for the common fungal pathogens infecting water hyacinth.

Plastic basins with a diameter of $90 \mathrm{~cm}$ were acquired and filled with water drawn from Lake Victoria. The basins were arranged at $30 \mathrm{~cm}$ from each other along a bench in the Botanic Garden glasshouse.

Young healthy plantlets obtained from the lake, with relatively small leaves and short petioles and of approximately the same age with 5 leaves per plant were selected. Individual plants were placed into the basins. Three plants were placed in each of the basins. A single handful of soil was added in the bottom of each container along with a table spoonful of DAP fertilizer following the recommendations of Dhingra and Sinclair (1995) to ensure the plants remained green and healthy pending the commencement of the trial. The plants were allowed three days to acclimatize. The pathogen was formulated in the oils to make 12 formulations as shown in Table 1.
Table 1 Oil formulations

\begin{tabular}{llllll}
\hline Oil & $\begin{array}{l}\boldsymbol{A} . \\
\text { (spores/ml) }\end{array}$ & $\begin{array}{c}\text { zonatum } \\
\text { (spore }\end{array}$ & concentration \\
\cline { 2 - 5 } & $\mathbf{1 x 1 0}^{\mathbf{5}}$ & $\mathbf{1 \times 1 0 ^ { 6 }}$ & $\mathbf{1 x 1 0}^{\mathbf{7}}$ & $\mathbf{1 x 1 0}^{\mathbf{8}}$ \\
\hline Corn oil & 1 & 2 & 3 & 4 \\
Mineral oil & 5 & 6 & 7 & 8 \\
Glycerol & 9 & 10 & 11 & 12 \\
\hline
\end{tabular}

The twelve formulations plus the control were replicated three times and randomly arranged in a completely randomized design (CRD) on the glasshouse floor. After three days of acclimatization, all the healthy and fully expanded leaves were injured by being pricked with as sterile needle and washed with sterile distilled water according to the procedure of Firehun $\boldsymbol{e t}$ al (2006). The plants in the pots were sprayed with the corresponding oil formulation until the leaves were fully wetted by the spray. The hand sprayer was held at $45^{\circ}$ and at a distance of $20 \mathrm{~cm}$ from the plants. The control was sprayed with sterile distilled water. To ensure sufficient moisture for infection, a fine mist of sterile water was sprayed upon the leaves after the mycoherbicide spray droplets had evaporated according to procedure followed by El Morsy (2004).

Disease severity scoring was done using the Modified Naseema et al. (2001) disease rating scale as shown in Table 2.

Table 2 Modified Naseema et al. (2001) disease severity rating scale

\begin{tabular}{ll}
\hline $\begin{array}{l}\text { Disease severity } \\
\text { rating scale }\end{array}$ & $\begin{array}{l}\text { Type of symptom produced/ } \\
\text { symptom description }\end{array}$ \\
\hline 1 & $\begin{array}{l}\text { No zonate spot symptom } \\
1-9 \% \text { necrotic symptom developed } \\
\text { around the pin pricked area only } \\
10 \% \text { of the leaf area showing } \\
2 \\
3\end{array}$ \\
$\begin{array}{l}\text { yellowing or browning with zonate } \\
\text { spots starting to show } \\
11-25 \% \text { of the leaf area showing } \\
\text { yellowing and/or browning, zonate } \\
\text { spots clearly visible } \\
26-50 \% \text { of the leaf area including } \\
\text { petiole showing clear zonate spot } \\
\text { symptoms } \\
51-100 \% \text { of the leaf area including } \\
\text { petiole showing zonate symptoms, } \\
\text { necrosis of the leaves beginning to } \\
\text { show }\end{array}$ \\
6
\end{tabular}

A two-way ANOVA was conducted using SPSS version 20 to compare the main effects of oil for formulation and the spore density as well as their interaction effects on disease severity. A post hoc test was also conducted to determine the means were different.

\section{Results}

Physical examination of the culture revealed colonies that grew slowly covering the entire media in 8-10 days. They were initially compact and moist later turning white, felted and fluffy. The colonies later on darkened starting from the middle part. Low power (x10) microscopy on the white, felted and fluffy material revealed hyaline, fine, septate and branched mycelia. Slides made from at low magnification revealed conidia that were unicellular, and appeared to form unconnected chains and/or were simply scattered. They were cylindrical with a slight tapering towards one end. After 10 days, disease symptoms characterized by zonate spots suggesting the presence of $A$. zonatum infection were noticed on the previously injured leaves on which $5 \mathrm{~mm}$ diameter agar blocks of the pure 
culture had been placed. During the study period, in both pathogenicity and efficacy tests, the pathogen caused disease infection that was noticeable and could be scored using the scoring scales for this study.

Table 3 Results of disease severity at the end of study period

\begin{tabular}{llll}
\hline Spore density & Corn oil & Mineral oil & Glycerol \\
\hline $1 \times 10^{5}$ & 3.3 & 1.7 & 2.8 \\
$1 \times 10^{6}$ & 2.7 & 1.0 & 2.3 \\
$1 \times 10^{7}$ & 2.3 & 0.7 & 1.4 \\
$1 \times 10^{8}$ & 1.0 & 0.3 & 0.9 \\
\hline Mean & 2.3 & 0.9 & 1.9 \\
\hline
\end{tabular}

The results of ANOVA showed that the variances of the groups were not equal according to the Levene's test of homogeneity of variance $(F(11,28)=2.53, p=.023)$. Oil and spore density effects were statistically significant at $p<0.05$. The main effect of oil yielded an effect size of 0.281 indicating that $28.1 \%$ of the variance in disease severity was explained by oil formulation. $(F(2,28)=5.459, p=0.01)$. The main effect of spore density yielded an effect size of 0.326 indicating that $32.6 \%$ of the variance in the study was explained by spore density $(\mathrm{F}(3,28)=$ $4.515, \mathrm{p}=0.011)$. The interaction effect was not significant $(\mathrm{F}(6$, $28)=0.199, p=0.974)$, indicating that there was no combined effect for the kind of oil used in the formulation of the A. zonatum and the spore density in the study.

The results of post-hoc test as tabulated in Table 4 indicated that corn oil and glycerol were not significantly different as formulation materials and they were both better than mineral oil.

Table 4 Results of post hoc test

\begin{tabular}{lllll}
\hline Variable & Variable & Mean & P & Remarks \\
1 & 2 & DS & value & \\
& & & &
\end{tabular}

\begin{tabular}{clccl} 
Corn oil & Glycerol & 2.3 & .324 & $\begin{array}{l}\text { Difference not } \\
\text { significant. Corn oil } \\
\text { better than glycerol } \\
\text { as formulation } \\
\text { material }\end{array}$ \\
Corn oil & $\begin{array}{l}\text { Mineral } \\
\text { oil }\end{array}$ & 0.9 & .003 & $\begin{array}{l}\text { Difference } \\
\text { significant Corn oil } \\
\text { better than mineral } \\
\text { oil as formulation } \\
\text { material } \\
\text { Difference } \\
\text { significant Glycerol } \\
\text { better than mineral } \\
\text { oil }\end{array}$ \\
\hline
\end{tabular}

\section{Discussion}

The study has confirmed that Acremonium zonatum is pathogenic on water hyacinth plants i.e. it is able to cause disease on water hyacinth. Its virulence, or its degree of pathogenicity, is low. This was evidenced by the fact that there was no mortality to the water hyacinth plants at the end of the study period. However, a reduction in plant growth was exhibited in the inoculated plants. The reduction in plant growth was presumably attributed to the severe stress caused by the pathogen to the plants, which affected the ability of the mature plants to produce strong fresh leaves and daughter plants. This observation confirms the findings of Shabana et al. (1995). The inability of the isolates to cause mortality to the plants during the study period was possibly due to the reduced virulence of the isolates caused by repeated sub-culturing, which was carried out five times during single spore isolation. Loss of virulence and changes in some growth characteristics after repeated subculturing of pathogens has been reported by Nyvall and Hu (1997). This is further confirmed by Gaur et al (2013) who reported that the major factors favoring disease emergence are genetic change in the pathogen and host population and changes in host ecology and environment. International experience shows that the water hyacinth's reproductive capacity, adaptability, nutritional requirements and resistance to adverse environments make it impossible to eradicate, and difficult to control especially with a single method (Harley, 1990; Gutiérrez et al. 1994).

For all the four oil emulsions, disease infection was noticed to increase with increasing spore concentration. The most effective formulation in causing disease infection in water hyacinth plants was corn oil with $1 \times 10^{8}$ spores/ml. Disease infection declined with reducing spore concentrations. This confirms the findings of Walker and Tilley (1979) who reported that a there is a positive linear relationship between inoculum concentration and disease infection for potential mycoherbicide agents. At low spore density in corn oil, the disease infection also occurred. The susceptibility of water hyacinth plants even at low spore densities may be attributed to the physiological state and age of the plants. Pathogens that can cause disease infection at low doses are considered potentially most promising agents for mycoherbicide development (Spotts and Cerventes, 1991). According to Womack et al. (2002), the use of less viscous vegetable oil, such as corn oil, is advantageous for overcoming the need to physically cover the infected leaves with polythene material to increase moisture for enhanced infection after inoculation. The oil encloses the moisture lost from the leaves and this becomes available to provide the moist micro climate that is necessary for infection to effectively take place. Karim et $\boldsymbol{a l}, \mathbf{2 0 1 1})$ also found that vegetable oil formulations generally improve the efficacy of mycoherbicides.

Fernandez and Juncosa (2002) reported that temperature and humidity are the main constraints to the effectiveness of fungal pathogen growth. Several adjuvants have been reported to improve the germination of spores, enhancing the activity of fungal pathogens. This is necessary for infection to take place. Glycerol is a preservative that has little chemical effect on fungal spores. It immobilizes the spores making infectivity to go down. Its more important role is therefore in preserving fungal spores rather than being used in mycoherbicide formulation.

Following inoculation with A. zonatum, leaf infection develops, favored by injury and free moisture. The oil emulsions enclose this moisture to make it available for spore germination.

The mycoherbicides tested showed no reaction to the tested crop plants. Mycoherbicides can be both specific and nonspecific. Agents that are regarded as most suitable for bio control are supposed to be host specific (Harris 1990). The host specificity test carried out in this study qualifies A. zonatum as a suitable candidate for bio control of water hyacinth.

\section{Conclusion}

The results of this study have proved $A$. zonatum is pathogenic to water hyacinth. This pathogenicity varies with different spore concentrations of the bio agent with $1 \times 108$ spores/ml being the most potent.

A. zonatum has favorable characteristics for consideration as a mycoherbicide though not a virulent one. It has a major weak point in that its effect on the water hyacinth plants is not accompanied by complete death. The pathogenicity of this mycoherbicide on water hyacinth plants varies with different spore concentrations particularly in corn oil emulsion. Corn oil is therefore a suitable carrier for the biocontrol agent. 


\section{Acknowledgement}

The authors wish to thank Maseno University Botany Department for facilitating the study.

\section{Declaration of interest}

The report no conflict of interest and are the only ones responsible for the content and writing of the paper.

\section{References}

1. Berestetskiy, A., \& Sokornova, S. 2018. Production and stabilization of mycoherbicides. Biological Approach for controlling weeds. Intech open publishers, 1:63-88.

2. Biswajit, B. \& Kamal, U. A. 2019. A review on lake eutrophication dynamics and recent developments in lake modeling. Ecohydrology \& Hydrobiology, 19, 155-166. https://doi.org/10.1016/j.ecohyd.2018.03.002

3. Bordin, E. R., Camargo, A. F., Stefansky, F. S., Scapini, T., Bonatto, C. \& Zanivan, J. 2020. Current production of bioherbicides: mechanisms of action and technical and scientific challenges to improve food and environmental security. Biocatalysis and biotransformation, 1-14. https://doi.org/10.1080/10242422.2020.1833864

4. Caprette R. D. 2000. Bioslabs methods/Microscopy cell counting, Rice University, USA.

5. Dersseh, M. G. \& Dessalegn, C. D. 2019. Water hyacinth: review of its impacts on hydrology and ecosystem services - lessons for management of Lake Tana. Extreme hydrology and and ecosystem services-Lessons for management of Lake Tana. Extreme hydrology and climate variability, 237-251. https://doi.org/10.1016/B978-012-815998-9.00019-1

6. Fawad, M. and JAMAL, A. (2019). Water hyacinth: utilization and impact on biodiversity. Black Sea Journal of Agriculture, 2, 58-62.

7. Dhingra O.D. \& Sinclair J.B. 1995. Basic Plant Pathological Methods, $2^{\text {nd }}$ ed. Lewis Publ., London, 448.

8. El-Morsy, E. 2004. Evaluation of micro fungi for the biological control of water hyacinth in Egypt. Fungal Diversity 16, 35-51

9. Fernandez, C., Juncosa R. 2002. Biopesticides: agriculture of the future Phytomer 141, 14-19

10. Firehun, Y., Tariku G. \& Abera, T. 2006. Water hyacinth status and its management at Wonji- Shoa Sugar Factory (Amharic Version). $A$ paper presented on the awareness creation workshop on water hyacinth, Ethiopian Sugar Industry Research and Training Service. March 2006. Wonji, 12-18.

11. Flora, T. O., Oni, E., Kareem, S. O., Adebukunola, O. \& Adelodun, L. K. 2018. Extent of microbial contamination of refined and unrefined vegetable oils sold in South-West Nigeria. Turkish journal of agriculture - Food science and technology, 6, 396-400. https://doi.org/10.24925/turjaf.v6i4.396-400.1430

12. Gaur, R.K., John, T. \& Sharmar, P. 2013. Plant-Virus host interaction. Molecular Approach and Viral Evolution. eBook published by Elsevier Science, 430, eBook ISBN: 9780124115989

13. Gutiérrez, E., Arreguín, F., Huerto, R. \& Saldaña, P. 1994. Aquatic weed control. International Journal of Water Resources Development 10, 291-312. https://doi.org/10.1080/07900629408722631

14. Harley, K.L.S. 1990. The role of biocontrol control in the management of water hyacinth, Eichhornia crassipes. Biocontrol News and Information 11, 11-22

15. Harris P 1990. Environmental Impact Assessment of Introduced Biological Control Agents. In "critical issues in Biological Control" (Ed. M. Mackaur, L. E. Ehker and J Roland 289-300. Intercept, Andover.

16. Karim, D., Rachid L., Mamourou, D. \& Haissan, M. J. 2011. Production and oil emulsion formulation of Cadaphora malorum and Alternaria jacinthicola, two bio control agents against water hyacinth (Eichhornia crassipes). African Journal of Microbiology Research 5, 924-929.

17. Konuskan, D. B., Arslan, M. and Oksuz, A. 2019. Physicochemical properties of cold pressed sunflower, peanut, rapeseed, mustard and olive oils grown in the Eastern Mediterranean region. Saudi Journal of Biological Sciences, 26, 340-344. https://doi.org/10.1016/j.sjbs.2018.04.005

18. Martinez, J.M. \& Charudattan, R. 1998. Survey and evaluation of Mexican native fungi for biocontrol of water hyacinth. J. Aquatic. Plant Management, 36, 145-148.
19. Mengist, Y., \& Moges, Y. 2019. Distribution Impacts and Management options for water hyacinth (E. crassipes) in Ethiopia: A Review. Journal of Advances in Agriculture https://doi.org/1024297/jaa.v10i0.8308

20. Naseema, A., Praveena, R., Balakrishnan, S., Peethambaran, \& C.K. 2001. Management of water hyacinth [Eichhornia crassipes (Mart) Solms- Laubach] with fungal pathogens. The British Crop Protection Council Conference, Weeds, 1, 263-268.

21. Nyvall, R.F. \& Hu, A. 1997. Laboratory Evaluation of Indigenous North American Fungi for Biological Control of Purple Loosestrife. Biological Control 8, 37-42. https://doi.org/10.1006/bcon.1996.0482

22. Obianuju, P., Mulala, D. S., S’phumele, L., Nkomo L. Ntandoyenkosi, M. M. \& Nagendra, G. P. (2020). The benefits of water hyacinth (E. crassipes) for Southern Africa: A review. Sustainability journal, 12, 9222. https://doi.org/10.3390/su12219222

23. Olga, F. 1986. Moulds and filamentous fungi in technical microbiology; In: Progress in industrial microbiology, vol. 22 by SNTL publishers of Technical Literature, Prague.

24. Shabana, Y. M., Charudattan, R., \& Elwakil, M. A. 1995. Identification, Pathogenicity, and Safety of Altenaria eichhorniae from Egypt as a Bioherbicide Agent for Water hyacinth. Biological Control 5, 123 135. https://doi.org/10.1006/bcon.1995.1015

25. Spotts, R.A., and Cervantes, L. A.1991. Effect of Temperature and Wetness on Infection of Pear by Ventura pirina and the Rrelationship between Preharvest inoculation and storage scab. Plant Disease 75 1204-1207

26. Su, W., Sun, Q., Xia, M., Wen, Z. \& Yao, Z. (2018). The resource utilization of water hyacinth and its challenges. Journal of Urban Mining for Resource Supply, 7:46, Variability, 1: 1.

27. Walker, H. L., and Tilley, A. M. 1997. Evaluation of an isolate of Myrothecium verrucaria from sicklepod Senna obtusifolia as a Potential Mycoherbicide Agent. Biological control, 10(2), 104-112. https://doi.org/10.1006/bcon.1997.0559

28. Womack, G. J., Gillian M. E. and Burge M. N. 2002. A vegetable oil based inert emulsion for mycoherbicide delivery. Department of Bioscience and Biotechnology, University of Strathclyde, The Todd Centre, 31 Taylor Street, Glasgow, G4 ONR, United Kingdom.

29. Yigermal, H., Nakachew, K. \& Assefa, F. 2020. Distribution, threats and management options for water hyacinth (E. crassipes) in Ethiopia: A review. Journal of research and weed science, 3, 9-23. https://doi.org/10.26655/IRWEEDSCI.2020.1.2 